\title{
A new Mammutidae (Proboscidea, Mammalia) from the Late Miocene of Gansu Province, China
}

\author{
DIMILA MOTHÉ ${ }^{1,2}$, LEONARDO S. AVILLA ${ }^{2,3}$, DESI ZHAO $^{4}$, GUANGPU XIE $^{5}$ and BOYANG SUN \\ ${ }^{1}$ Programa de Pós-Graduação em Ciências Biológicas (Zoologia), Museu Nacional/Universidade Federal do \\ Rio de Janeiro, UFRJ, Quinta da Boa Vista, São Cristóvão, s/n, 20940-040 Rio de Janeiro, RJ, Brasil \\ ${ }^{2}$ Laboratório de Mastozoologia, Departamento de Zoologia, Universidade Federal do Estado do Rio \\ de Janeiro, UNIRIO, Av. Pasteur, 458, sala 501, Urca, 22290-255 Rio de Janeiro, RJ, Brasil \\ ${ }^{3}$ Programa de Pós-Graduação em Biodiversidade Neotropical, Universidade Federal do Estado do Rio \\ de Janeiro, UNIRIO, Av. Pasteur, 458, sala 506 A, Urca, 22290-255 Rio de Janeiro, RJ, Brasil \\ ${ }^{4}$ Gansu Industrial Occupational Technology College, Tianshui 741025, China \\ ${ }^{5}$ Gansu Provincial Museum, Lanzhou 730050, China \\ ${ }^{6}$ Tianjin Museum of Natural History, Tianjin 300201, China
}

Manuscript received on April 15, 2015; accepted for publication on July 13, 2015

\begin{abstract}
The "Yanghecun specimen", a proboscidean specimen represented by a mandible from Miocene of China and previously described as Gomphotheriidae, is here reviewed and described as a new genus and species of Mammutidae: Sinomammut tobieni. This taxon is a longirostrine mastodon, lacking lower tusks, and bearing a wide last molar with oblique and non-inflated lophids, broad transverse interlophids, and yoke-like wear figures. Phylogenetic analysis of Mammutidae based on dental and mandibular features recovered $S$. tobieni as sister group of the mastodon Mammut. The longirostrine condition and the well-developed lower incisors seem to be primitive for Mammutidae, while the brevirostry is the derived condition, probably emerged during the middle Miocene (12-11 Mya). However, two derived conditions are recognized to the lower tusks: the absence of lower tusks (S. tobieni) and the occasional presence of vestigial lower tusks (Mammut).
\end{abstract}

Key words: Evolution, Longirostrine symphysis, Mammutidae, Miocene, Proboscidea.

\section{INTRODUCTION}

The fossil record of the Proboscidea in China is abundant, however, its diversity is still being discovered, as the temporal distribution range of several genera (Tobien et al. 1986, 1988, Wang and Deng 2011, Wang et al. 2012, 2013). Recently, a very fragmentary fossil of a proboscidean with

Correspondence to: Dimila Mothé

E-mail: dimothe@hotmail.com longirostrine and a tuskless lower jaw from the Miocene of China (GIOTC 0982-9-178, the "Yanghecun specimen" of Wang et al. 2014) was recognized (but not named) as a new genus and species of the family Gomphotheriidae. Also, the authors related this unnamed new taxon to the Asian trilophodont brevirostrine gomphothere Sinomastodon, and proposed to include them both in the subfamily Sinomastodontinae (Wang et al. 2014). 
Two decades ago, an almost complete proboscidean mandible was discovered in a field work, the "Yanghecun specimen". The specimen is from the Yanghecun locality, Changdao Township, Xihe County, China, probably from the Upper Miocene strata (see Wang et al. 2014 for detailed discussion). Unfortunately, most part of the specimen has been lost and only the right mandibular ramus, bearing $\mathrm{m} 2$ (second lower molar) and $\mathrm{m} 3$ (third lower molar), as well as a photo of the specimen in situ (Fig. 1a), were preserved. However, a detailed analysis of the "Yanghecun specimen" revealed several morphological features that preclude its recognition as a member of Gomphotheriidae. Instead, these features suggest that the "Yanghecun specimen" is probably a new taxon of Mammutidae.

In this way, the objective of this study is to redescribe the "Yanghecun specimen", providing a formal description and diagnosis for a new genus and species, and presenting its phylogenetic position within the Mammutidae.

The ZooBank Life Science Identifier (LSID) of this publication is: urn: 1sid: zoobank.org: pub: 52076E6F-8344-4650-B7BE-A830CBED3130.

\section{MATERIALS AND METHODS}

Morphological comparisons were conducted for dental and mandibular specimens of Gomphotheriidae and Mammutidae housed at the collections of the American Museum of Natural History (AMNH), United States; Florida Museum of Natural History (FLMNH), United States; and Gansu Industrial Occupational Technology College (GIOTC), China.

The Mammutidae analyzed here includes all genera described and recognized in the current literature: Zygolophodon (Tobien 1975, Janis et al. 1998, Markov 2004, Codrea et al. 2005, Göhlich 2010), Mammut (Barbour 1931, Shoshani and Tassy 1996, Janis et al. 1998, Markov 2004)

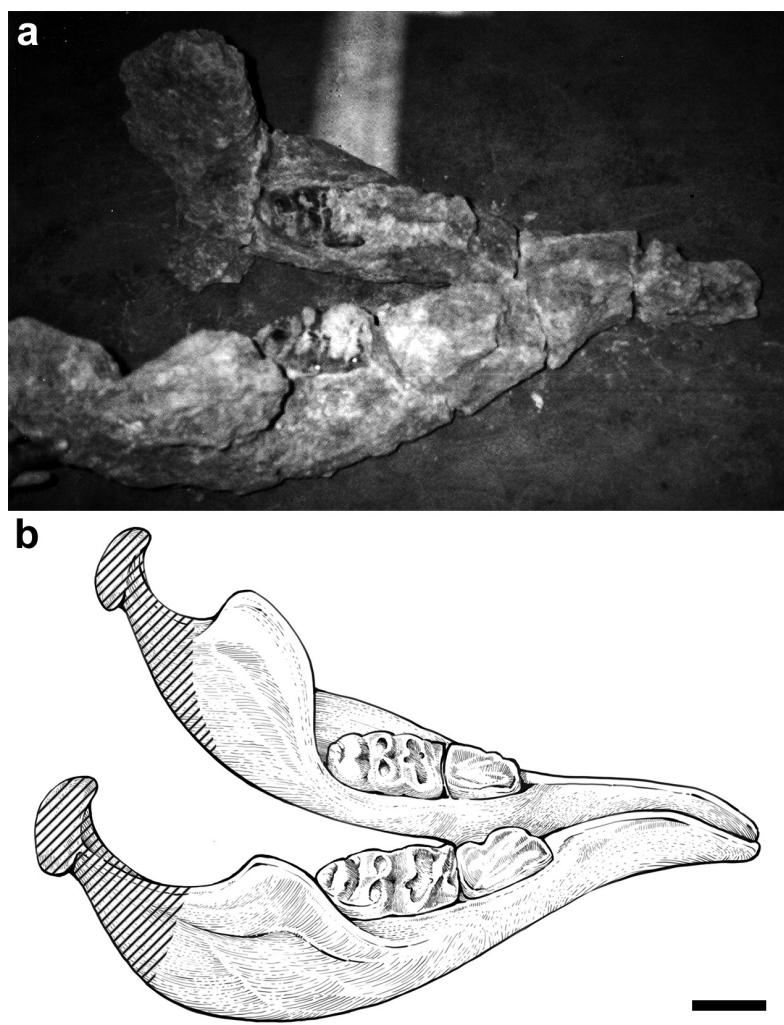

Figure 1 - The original record of "Yanghecun specimen". Note the longirostrine symphysis fragmented in two pieces (on the right). (a) Original photo of the complete specimen, an almost complete lower jaw; (b) Reconstructed sketch of Yanghecun specimen based on original picture in (a) by Pablo Lara. The region of the condyles (hachured area) was reconstructed based on Mammut americanum and may not correspond anatomically to Sinomammut. Scale bar: $10 \mathrm{~cm}$.

and Eozygodon (Tassy and Pickford 1983). We did not include the African taxon Losodokodon losodokius (Rasmussen and Gutierrez 2009) in the phylogenetic analysis, because it is known only by two upper molars (none mandibular, lower molars and/or tusks specimens), and so it is not comparable to the "Yanghecun specimen". Furthermore, some authors suggested that the Eurasian Mammut is polyphyletic (see Markov 2004, Garevski et al. 2012). The taxonomy of Mammut is not the scope of this study. Thus, this genus is represented in our phylogenetic analysis by Mammut americanum (including the temporal distribution from late Miocene to late Pleistocene, from North and Central Americas, see Janis et al. 
1998). The Gomphotheriidae specimens analyzed included the taxa Gomphotherium, Tetralophodon, Sinomastodon and Anancus. The molars structures studied here followed the anatomical nomenclature of Tobien (1975). The length and height of the third lower molars (m3) were used to compare Mammutidae and Gomphotheriidae specimens.

We performed a phylogenetic analysis with the help of the TNT software (Goloboff et al. 2008) using exact search (Implicit enumeration) in order to elucidate the relationships of the new taxon within the Mammutidae. All characters were unordered and equally weighted (value $=1$ ). Additionally to the new taxon here described, the ingroup is composed by all Mammutidae genera (the "Yanghecun specimen", Zygolophodon, Mammut and Eozygodon). We are proposing a new data matrix including thirteen dental and mandibular characters (Table I). In accordance to their relationships to the Mammutidae in Gheerbrant and Tassy (2009), the selected outgroup is represented by the genera Eritreum and Phiomia.

\section{RESULTS AND DISCUSSIONS}

Although the specimen GIOTC 0982-9-178 was originally recognized as a member of Gompho- theriidae and more close related to the genus Sinomastodon (Wang et al. 2014), the presences of oblique and non-inflated lophids, broad transverse valleys between lophids, and wide $\mathrm{m} 3$ with yokelike wear figures securely includes this specimen in family Mammutidae, which has the zygodont cheek dentition as one of its most important diagnostic feature (Tobien 1975).

The morphology of zygodont molars share some similarities with the bunodont molars of the Gomphotheriidae, as the subdivision of the transverse crests by a median sulcus in half lophs(lophids), which are built up by two or more small cones (the main cusp and the associated mesoconelet; see figure 3 of Tobien 1975), and the presence of a variable number of central conules and accessory conelets.

However, the central conules, or anterior and posterior crescentoids ( $\mathrm{ACr}$ and $\mathrm{PCr}$, respectively), in bunodont molars are pillar-like and markedly separated from the main cusp, while in the zygodont molars, these structures form enamel crests on posttrites (Po) and crest-like crescentoids on pretrites (Pr) (Tobien 1975, Tassy 2014). Furthermore, the wear figures in bunodont molars are usually shaped as a simple or double bounded

TABLE I

Character-taxon matrix used in the cladistic analysis of the Mammutidae, including the new taxon Sinomammut tobieni. Missing data (either due to non-preservation or because non-applicable) are coded as "?". Dental, cranial and mandibular characters are: 1) Antero-posterior compression of lophs/lophids on molars: (0) absent (1) present; 2) Crestlike crescentoids on pretrites (0) absent (1) present; 3) Cheek tooth in use simultaneously (0) M1-M3 with other anterior molars (1) only M1-M3 (2) M1-M3 simultaneously in use; 4) Tritolophid of $M_{2}$ (0) shortened (1) enlarged; 5) Upper permanent tusks (0) shorter than lower jaw (1) longer than lower jaw; 6) Upper permanent tusks with lateral enamel band (0) absent (1) present; 7) Lower tusks shape (0) concave dorsally (1) straight; 8) Lower tusks cross section (0) flattened (1) rounded or oval; 9) Upper tusks laterally divergent (0) little divergent (1) very divergent; 10) Upper tusks

(0) downcurved (1) upcurved; 11) Presence of lower tusks (1) present (2) absent; 12) Lower jaw symphysis length (0)

longirostrine (1) brevirostrine; 13) Pronounced crest-like habitus on molar lophs/lophids (0) absent (1) present.

\begin{tabular}{|c|c|c|c|c|c|c|c|c|c|c|c|c|c|}
\hline Taxa & 1 & 2 & 3 & 4 & 5 & 6 & 7 & 8 & 9 & 10 & 11 & 12 & 13 \\
\hline Phiomia & 0 & 0 & 0 & 0 & 0 & 0 & 0 & 0 & 0 & 0 & 0 & 0 & 0 \\
\hline Eritreum & 0 & 0 & 1 & 1 & $?$ & $?$ & 0 & 0 & $?$ & $?$ & 0 & 0 & 0 \\
\hline Zygolophodon & 1 & 1 & 2 & 1 & 1 & 1 & 1 & 1 & 0 & 0 & 0 & 0 & 0 \\
\hline Euzygodon & 1 & 1 & 2 & 1 & 1 & 1 & 0 & 0 & 0 & 0 & 0 & 0 & 0 \\
\hline Mammut & 1 & 1 & 2 & 1 & 1 & 0 & 1 & 1 & 1 & 1 & {$[01]$} & 1 & 1 \\
\hline Sinomammut & 1 & 1 & 2 & 1 & $?$ & $?$ & $?$ & $?$ & $?$ & $?$ & 1 & 0 & 1 \\
\hline
\end{tabular}


trefoil (which may vary according with the number of accessory conelets, see Mothé and Avilla 2015), while wear figures in zygodont molars are more slender and diamond-shaped, due the antero-distal compression of lophs(lophids) and the crest-like shape of the crescentoids and enamel crests (simple form, more or less prominent). Thus, the wear figures in zygodont molars have spindly, unrounded and thin projections (exposed dentin; Tassy 2014).

Although the Mammutidae had a worldwide distribution, absent only in South America, Australia and Antarctica (Shoshani and Tassy 1996), it was one of the less diversified families within Elephantimorpha (Gheerbrant and Tassy 2009). Until now, the most geographically restricted genus was Eozygodon, which is recorded only in Africa (Tassy and Pickford 1983); the widespread genus Zygolophodon is recorded in Africa, Eurasia, North America; and Mammut is recorded in Eurasia, North and Central Americas (Tobien 1975). Notwithstanding, the morphological similarity with other Mammutidae taxa, the specimen GIOTC 0984-9-178 presents several unique features (these will be presented in the sequence). Thus, the specimen GIOTC 0984-9-178 is a new genus and species of Mammutidae from the Miocene of China and, despite the description of Sinomammut tobieni increases the diversity of the Mammutidae, this new monospecific genus probably represents a Chinese endemic taxon.

SYSTEMATIC PALEONTOLOGY

PROBOSCIDEA Illiger, 1811

MAMMUTIDAE Hay, 1922

SINOMAMMUT TOBIENI gen. et sp. nov.

(Fig. 1, 2 and 3)

Sinomastodon intermedius Xie 2007, p. 169, figure 31

Sinomastodontinae genus et species indeterminata, Wang et al. 2014, p. 5, figure 4

ZooBank Life Science Identifier (LSID) urn: 1sid: zoobank.org: act 7B1FF891-0595-43398C82-7F42528931D7
Etymology - the genus name, Sino, from the latin Sinae, meaning Chinese, plus mammut, in reference to the type genus of the family Mammutidae; and, the species is named after Dr. Heinz Tobien, a great promotor of the research on Chinese Proboscidea.

Temporal, Stratigraphic and Distributional Range- Baodean (Chinese Neogene Land Mammal age), Late Miocene (Wang et al. 2014).

Holotype-GIOTC 0984-9-178, a fragmentary right lower hemimandible bearing fully worn $\mathrm{m} 2$ and moderately worn $\mathrm{m} 3$.

Type Locality - Yanghecun locality, Changdao Township, Xihe County $\left(35^{\circ} 08^{\prime} 38.1^{\prime \prime} \mathrm{N}\right.$, 105²0’29.1”E), China.

Type Horizon- Upper Miocene strata, situated in the center of the Xihe-Lixian Basin in the West Qingling fold belt. It is composed of brownish-red silty mudstone and mudstone, partially intercalated with conglomerates, sandy conglomerates, and coarse sandstones. The Upper Miocene is distributed in a band in a gully, unconformity overlying the Xihanshui Group (Wang et al. 2014).

Diagnosis - a new monospecific genus of Mammutidae from China, known from a single robust and longirostrine mandible, with straight, thin and tuskless symphysis (the symphysis region was broken and lost during collection procedures). The zygodont cheek teeth include a trilophodont $\mathrm{m} 2$ and a tetralophodont $\mathrm{m} 3$. The $\mathrm{m} 3$ lophids are compressed anteroposteriorly and obliquely oriented (i.e., antero-lingual to postero-labial direction); its Prs have crest-like $\mathrm{ACr}$ and $\mathrm{PCr}$ (Pr1 and Pr2 have crest-like PCr and Pr2, Pr3 and $\mathrm{Pr} 4$ have crest-like ACr) and Po1 and Po2 have posterior zygodont crests (ZC). A small and weak posterior cingulum $(\mathrm{PC})$ is present distal to the last Po; formed by six small cusps.

Description of material - the mandible has a robust body, with rounded labial portions; the longirostrine symphysis is relatively straight and thin. The original specimen presented a tuskless 
lower jaw (Fig. 1a). The ascending rami are fragmented and the condyles are not preserved (Fig. 1a).

The cheek teeth include both second (m2) and third (m3) molars (Fig. 2). The $\mathrm{m} 2$ is trilophodont, however, its broken at the protolophids level and totally worn; no diagnostic structures are observable on its crown (Fig. 2). The $\mathrm{m} 3$ is wide, tetralophodont and has a small PC; the lophids are compressed antero-posteriorly and oblique (i.e., antero-internal to postero-external direction), with clearly yoke-like crests (Fig. 2 and Fig. 3d). The lingual wall is vertical, while the labial wall is more oblique towards the tip of the cusps. The right $\mathrm{m} 3$ lophids are worn in different levels, with exposed dentine in all of them, except for the last one (Fig. $2 \mathrm{a})$. The protolophid is completely worn out and its anterior region is obliterated. The metalophid is sorely worn, but the enamel figures on Prs and Pos are still visible and the exposed dentine surfaces are medially connected. The last two lophids are slightly worn, but very well preserved; the fourth lophid has reduced width in relation to the anterior lophids.
All m3 Prs and Pos are composed by a developed primary connelet (PCo) and secondary connelet (SCo), which are smaller and weaker than the associated PCo. All right $\mathrm{m} 3$ Prs present developed crest-like $\mathrm{ACr}$ ( $\mathrm{Pr} 1$ crest-like $\mathrm{ACr}$ is absent or worn out), and the first two also present crest-like PCr (Fig. 3d). The Po3 and Po4 anterior and posterior $\mathrm{ZC}$ are absent. The $\mathrm{PC}$ of right $\mathrm{m} 3$ is small and weak, formed by six small cusps, more developed on the Po side (Fig. 3). There is a small accessory connelet (ACo) on labial side of third interlophid area (IA). The IA is broad and well delineated (Fig. 3d). The crest-like PCr of Pr1 and $\operatorname{Pr} 2$ make contact with the crest-like ACr of Pr2 and Pr3, which intersect the first and second IA. The crest-like ACr of $\operatorname{Pr} 4$ is slightly worn and do not connect with $\operatorname{Pr} 3$ (Fig. 3d).

Differential diagnosis-Sinomammut differs from Gomphotherium and other Gomphotheriidae taxa by having slender and oblique lophids on $\mathrm{m} 3$, which is inflated and more parallel in gomphotheres (Fig. 3d and e); by having ZC on $\mathrm{m} 3 \mathrm{Po}$ and $\mathrm{ACr}$ and $\mathrm{PCr}$ on $\mathrm{Pr}$, which are absent in
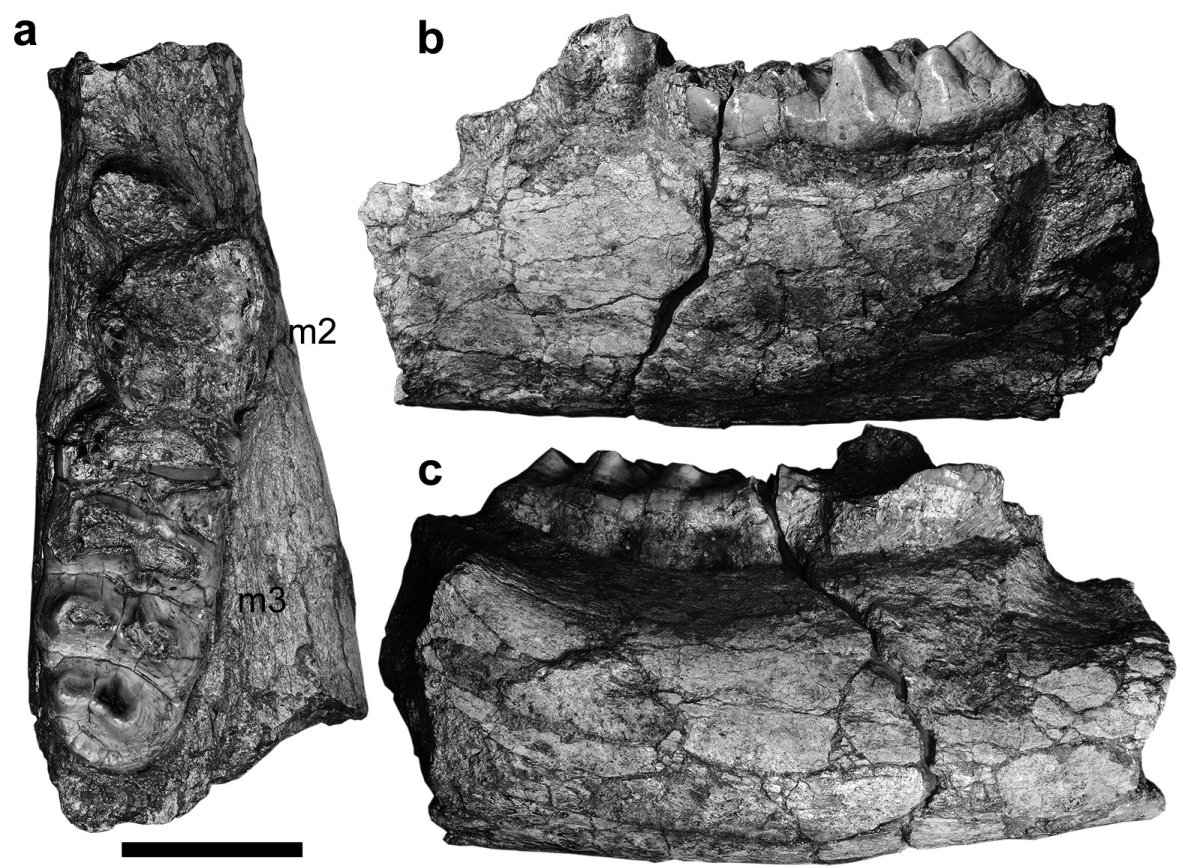

Figure 2 - Right fragmented mandible ramus of Sinomammut tobieni (GIOTC 0984-9-178) with $\mathrm{m} 2$ and $\mathrm{m} 3$. (a) Occlusal view; (b) Lingual view; (c) Labial view. Scale bar: $10 \mathrm{~cm}$. 
Gomphotheriidae; and by having proportionally wider $\mathrm{m} 3$ teeth (Fig. 4). The combination of a longirostrine and tuskless lower jaw (Fig. 1) differs Sinomammut from all other Mammutidae taxa, which have longirostrine mandible with lower tusks (Zygolophodon and Eozygodon) or brevirostrine mandible with variable presence of vestigial lower tusks (Mammut; see Table II). The presence of a complete ZC only on the Po1 and Po2 differ Sinomammut from Zygolophodon, which has developed ZC on all Pos, and from Mammut and Eozygodon, which have vestigial crests. The poorly
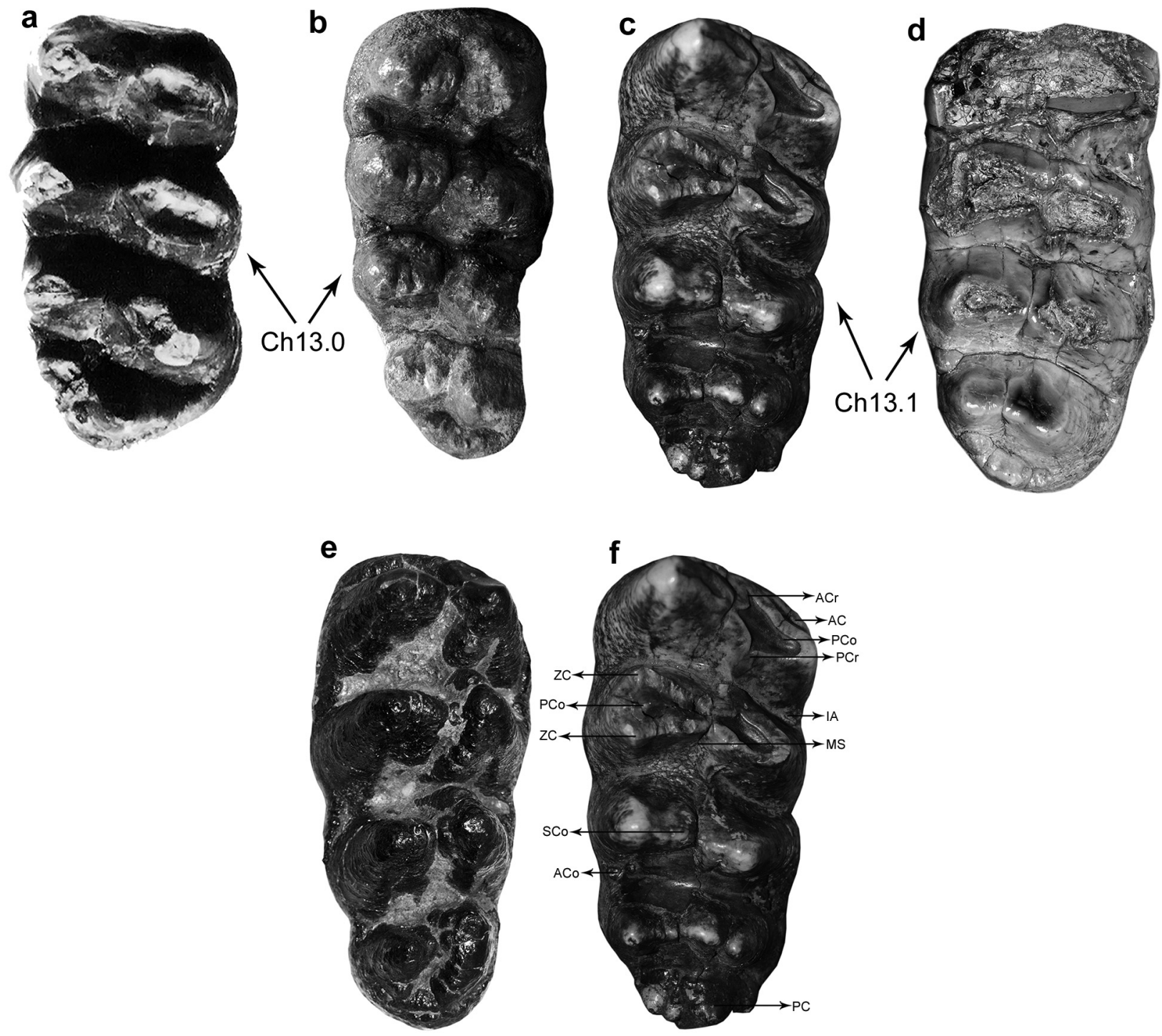

Figure 3 - Occlusal view of third lower molars (m3) of Mammutidae (a,b,c) and Gomphotheriidae (e) compared to m3 of Sinomammut tobieni gen. et sp. nov. (d). Note the difference between the molar morphology, the shape of wear figures and the molar structures studied in this paper (abbreviations are explained on text). (a) Eozygodon morotoensis right $\mathrm{m} 3$ (from Tassy and Pickford, 1983); (b) Zygolophodon right m3 (AMNH 26461); (c) and (f) Mammut americanum left m3 (AMNH 14294); (d) Sinomammut tobieni right m3 (GIOTC 0984-9-178); (e) Gomphotherium left m3 (AMNH 1908). Specimens (c), (e) and (f) are horizontally turned in order to facilitate anatomy recognition and comparisons. The only synapomorphy shared by $S$. tobieni and M. americanum - Presence of a pronounced crest-like habitus on molars - is indicated by the arrows and the abbreviation Ch13.1 (derived state, (c) and (d)) and Ch13.0 (primitive state, (a) and (b)). All specimens are out of scale. 
developed and lingually oriented PC (mainly behind last Po) differentiates Sinomammut from other Mammutidae taxa, in which the PC is well developed and lingually oriented (mainly behind last Po, as in Eozygodon), poorly developed and parallel to the last Po (Zygolophodon) or well developed and parallel to the last Po (Mammut).

The phylogenetic analysis performed here resulted in only one most parsimonious tree, with 15 steps, the topology as follows: (Eozygodon (Zygolophodon (Sinomammut tobieni, Mammut))) (see Fig. 5). A closest relationship between Sinomammut tobieni and Mammut is supported by one unambiguous synapomorphy: the emergence of the pronounced crest-like lophs/lophids (character 13, state 1; see Fig. 3a to d). The clade (Zygolophodon (Sinomammut tobieni, Mammut)) is supported by two synapomorphies: the straight shape (character 7 , state 1) and rounded/oval cross section of the lower tusks (character 8, state 1). The lower tusks in Eozygodon are well developed, elongated and dorsoventrally flattened, with two strong

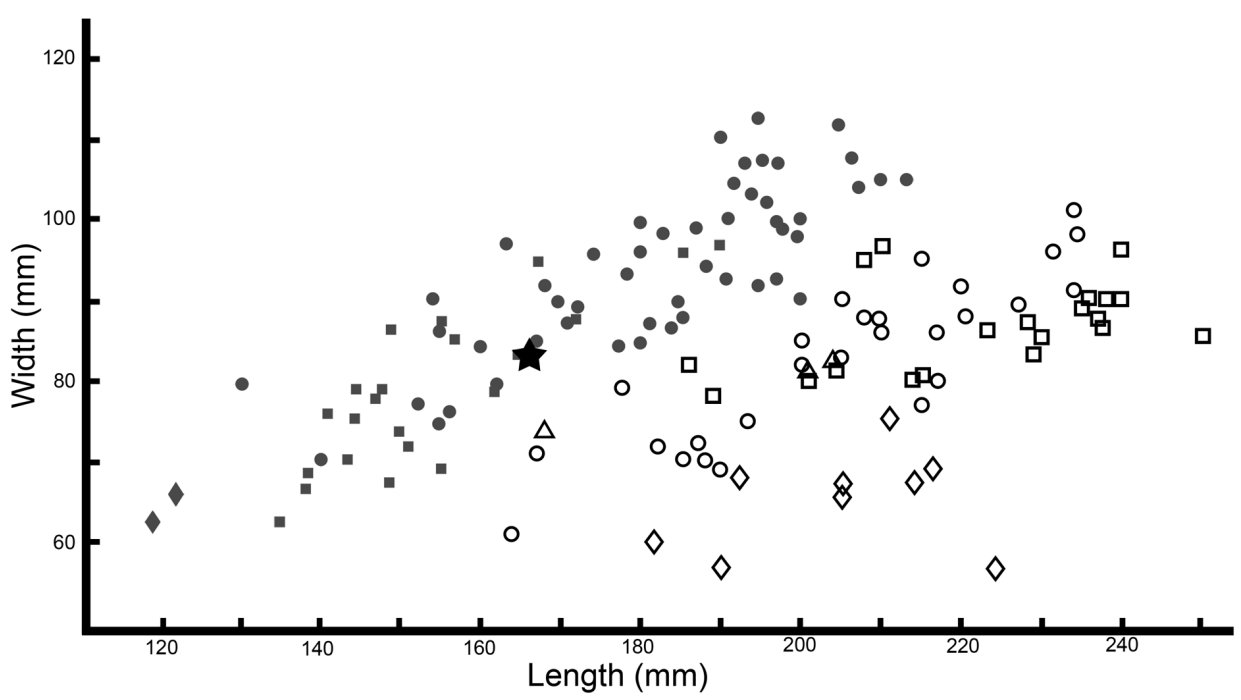

Figure 4 - Scatter diagram of late Neogene and Pleistocene Mammutidae and Gomphotheriidae m3 width and length. Note the difference between the Mammutidae cloud (gray dots) and Gomphotheriidae (open dots). Key: Sinomammut tobieni is represented by the black star; the genus Mammut is represented by the gray circles; Zygolophodon is represented by gray squares; Eozygodon is represented by gray diamonds; Tetralophodon is represented by open circles; Sinomastodon is represented by open triangles; Anancus is represented by open squares; Gomphotherium is represented by open diamonds. Data was based on Tobien (1975), Tassy and Pickford (1983), Shoshani and Tassy (1996) and Wang et al. (2014).

TABLE II

Sinomammut autapomorphies compared to Mammutidae taxa. Note that the set of features of Sinomammut is unique among the Mammutidae.

\begin{tabular}{cccc}
\hline Sinomammut & Eozygodon & Zygolophodon & Mammut \\
\hline Longirostrine and tuskless. & $\begin{array}{c}\text { Longirostrine with lower } \\
\text { tusks. }\end{array}$ & Longirostrine with lower tusks. & $\begin{array}{c}\text { Brevirostrine with or without } \\
\text { lower tusks. }\end{array}$ \\
$\begin{array}{c}\text { Small distal cingulum mainly } \\
\text { behind last Po. }\end{array}$ & $\begin{array}{c}\text { Well developed distal } \\
\text { cingulum mainly behind last } \\
\text { Po. }\end{array}$ & $\begin{array}{c}\text { Small distal cingulum behind } \\
\text { last lophid. }\end{array}$ & $\begin{array}{c}\text { Well developed distal } \\
\text { cingulum behind last lophid. }\end{array}$ \\
$\begin{array}{c}\text { Zygodont crests only on Po1 } \\
\text { and Po2. }\end{array}$ & Zygodont crests absent. & Zygodont crests on all Pos. & Zygodont crests absent. \\
\hline
\end{tabular}




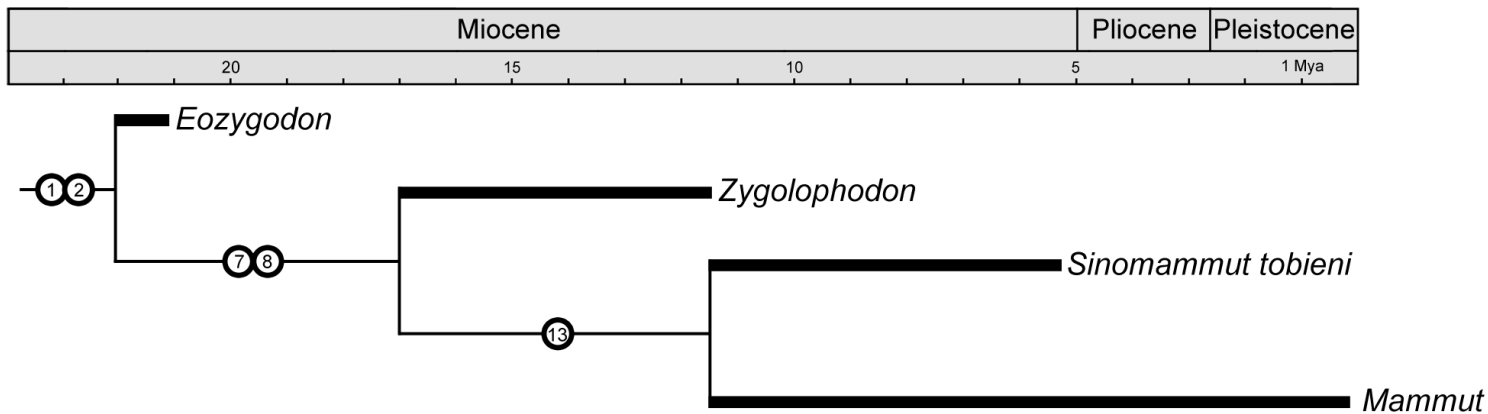

Figure 5 - Phylogenetic hypothesis of the family Mammutidae including the new mastodon Sinomammut tobieni. Diagnostic characters and states are described on Table I.

concavities (at the dorsal and ventral sides; Tassy and Pickford 1983).

The calibrated phylogeny of Mammutidae (following the previously cited literature for temporal range data) allowed the recognition of the diversification of the clade Sinomammut plus Mammut occurred during the late Early-Middle Miocene (17 to 11.6 Mya; Fig. 5). Although features related to mandibular symphysis length (brevirostrine/longirostrine condition) and to lower tusks (presence/absence) did not appear as synapomorphies, we recognize their importance to Mammutidae evolution. The longirostrine condition seems to be primitive for Mammutidae, and this condition is present in the earliest mastodon, Eozygodon, and also in Zygolophodon and Sinomammut. Thus, the brevirostrine condition of Mammut is the derived condition, and it probably emerged during the Middle to Late Miocene (17-12 Mya, see Fig. 5).

Concerning the lower tusks, the primitive condition for the Mammutidae is well-developed incisors, which is present in Eozygodon (see figure 15 of Tassy and Pickford 1983: 64) and Zygolophodon (see figure 39 in Tobien et al. 1988: 150). However, two derived conditions are recognized in the Mammutidae: the absence of lower tusks, as recorded for Sinomammut; and, the occasional presence of vestigial lower tusks or its absence, as seen in Mammut (Barbour 1931, Haynes 1991). The uniqueness of the longirostrine and tuskless mandible of Sinomammut can clearly differ this new taxon and Mammut - the latter is brevirostrine, but occasionally present small lower tusks (Barbour 1931), usually interpreted as sexual dimorphism. In fact, the loss of the lower tusks and the shortening of mandibular symphysis are evolutionary trends observed in parallel to other Proboscidea families (Shoshani and Tassy 1996), such as Gomphotheriidae and Elephantidae, from the late Miocene to Pliocene. Except for the gomphothere Rhynchotherium, which kept the lower tusks during all life span (Lucas and Morgan 2008), and Cuvieronius, which had deciduous lower tusks at immature stage (Ferretti 2008, D. Mothé, unpublished data), all Pleistocene/ Holocene proboscidean lineages (including the two extant elephants genera) are brevirostrine and dibelodont (presence of upper tusks and absence of lower tusks). These evolutionary trends in the mandible of Proboscidea are probably related to the several global climatic and environmental changes, which occurred from the late Middle Miocene on, causing modifications on feeding habits of those proboscideans (mastication mechanics, also modification in skull and molars morphology; see Maglio 1972), and probably included more abrasive vegetation, as C4 grasses, on diet (Janis 1988).

\section{CONCLUSIONS}

A new Mammutidae monospecific genus, Sinomammut tobieni, is described based on a longirostrine and tuskless partial lower jaw from 
the Miocene of China. This new taxon increases the diversity of the Family Mammutidae, originally composed by only four genera: Eozygodon, Zygolophodon, Mammut and Losodokodon. The phylogeny of Mammutidae here proposed positioned Sinomammut as the closest taxon of the worldwide mastodon Mammut, and they share one synapomorphy: the presence of pronounced crest-like on lophs/lophids of molars. These new mastodon also represents an important stage on the evolution of lower jaw and lower tusks in Proboscidea, since it is the is the unique completely tuskless longirostrine mammutid.

\section{ACKNOWLEDGMENTS}

The authors are grateful to all curators of the collections cited above for allowing the access to the Proboscidea specimens that supported this study; to Dr. Shiqi Wang, Dr. Taissa Rodrigues, Dr. Alexander Kellner, Dr. Marcelo Britto and Mrs. Sabrina Ferreira for improvements in content and English; to the two anonymous reviewers; Conselho Nacional de Desenvolvimento Científico e Tecnológico (CNPq) and Fundação Carlos Chagas Filho de Amparo a Pesquisa do Estado do Rio de Janeiro (FAPERJ) granted PhD scholarship funds to the author DM (process numbers 140453/201201, 201081/2014-8 and E-26/100.246/2014) and Conselho Nacional de Desenvolvimento Científico e Tecnológico (CNPq) granted Post-Doctoral scholarship funds to the author LA (248772/2013-9).

\section{RESUMO}

O "espécime de Yanghecun", uma mandíbula de proboscídeo do Mioceno da China e previamente descrito como Gomphotheriidae, é aqui revisado e descrito como um novo gênero e espécie de Mammutidae: Sinomammut tobieni. Este taxon é um mastodonte longirrostrino, sem presas inferiores, e com terceiro molar largo, com lofidos oblíquos e comprimidos, interlofidos amplos e com figuras de desgaste zigodontes. A análise filogenética de Mammutidae foi baseada em características dentárias, cranianas e mandibulares, e recuperou $S$. tobieni como grupo-irmão do mastodonte Mammut. A condição longirrostrina e as presas inferiores bem desenvolvidas seriam primitivas para Mammutidae, enquanto a brevirrostria seria a condição derivada, provavelmente surgida durante o Mioceno médio (12-11 Maa). Entretanto, duas condições derivadas são reconhecidas para as presas inferiores de Mammutidae: a ausência destes incisivos (S. tobieni) e a presença ocasional de incisivos vestigiais (Mammut).

Palavras-chave: Evolução, Mammutidae, Mioceno, Proboscidea, Sínfise longirrostrina.

\section{REFERENCES}

BARBOUR E. 1931. The Milford mastodon, Mastodon moodiei, sp. nov. A preliminary report. Bull Neb St Mus 24(1): 203210.

CODREA V, Venczel M AND POPA E. 2005. New finding of Mammut praetypicum (Proboscidea, Mammalia), a zygodont mastodon from Pgaia (NW Romania). Acta Palaeontol Rom 5: 67-71.

FERRETTI MP. 2008. A review of South American proboscideans. In: Lucas SG, Morgan GS, Spielmann JA and Prothero DR (Eds), Neogene Mammals. New Mex Museum Nat Hist Sci Bull 44: 381-392.

GAREVSKI R, GAREVSKA B AND MARKOV GN. 2012. Remains of Zygolophodon turicensis (Proboscidea, Mammutidae) from the coal mines near Bitola, Republic of Macedonia. Hist Nat Bulg 20: 157-162.

GHEERBRANT E AND TASSY P. 2009. L'origine et l'évolution des éléphants. Comptes Rendus Palevol 8: 281-294.

GÖHLICH UB. 2010. The Proboscidea (Mammalia) from the Miocene of Sandelzhausen (southern Germany). Palaontol Z 84: 163-204.

GOLOBOFF PA, FARRIS JS AND NIXON KC. 2008. TNT, a free program for phylogenetic analysis. Cladistics 24: 1-13.

HAYNES G. 1991. Mammoths, Mastodonts and Elephants: Biology, Behavior, and the Fossil Record. Cambridge University Press. Cambridge, $427 \mathrm{p}$.

JANIS CM. 1988. An estimation of tooth volume and hypsodonty indices in ungulate mammals, and the correlation of these factors with dietary preferences. Teeth Revisited: Proceedings of the VIIth International Symposium on Dental Morphology, 53, Paris, p. 367-387.

JANIS CM, SCOTT KM AND JACOBS LL. 1998. Evolution of Tertiary Mammals of North America. Vol 1: Terrestrial Carnivores, Ungulates, and Ungulatelike Mammals. Cambridge, New York, Melbourne: Cambridge University Press, $691 \mathrm{p}$.

LUCAS SG AND MORGAN GS. 2008. Taxonomy of Rhynchotherium (Mammalia, Proboscidea) from the 
Miocene-Pliocene of North America. In: Lucas SG et al. (Eds), Neogene Mammals, New Mex Mus Nat Hist Sc Bull 44: 71-87.

MAGLIO VJ. 1972. Evolution of mastication in the Elephantidae. Evolution 26: 638-658.

MARKOV G. 2004. The fossil proboscideans of Bulgaria and the importance of some Bulgarian finds - a brief review. Hist Nat Bulg 16: 139-150.

MOTHÉ D AND AVILLA LS. 2015. Mythbusting evolutionary issues on South American Gomphotheriidae (Mammalia: Proboscidea). Quat Sci Rev 110: 23-35.

RASMUSSEN DT AND GUTIERREZ M. 2009. A mammalian fauna from the Late Oligocene of northwestern Kenya. Palaeontographica A 288: 1-52.

SHOSHANI J AND TASSY P. 1996. The Proboscidea: Evolution and Palaeoecology of Elephants and Their Relatives. Oxford University Press. Oxford, 472 p.

TASSY P. 2014. L'odontologie de Gomphotherium angustidens (Cuvier, 1817) (Proboscidea, Mammalia): données issues du gisement d'En Péjouan (Miocène moyen du Gers, France). Geodiversitas 36(1): 35-115.

TASSY P AND PICKFORD M. 1983. Un nouveau mastodonte zygolophodonte (Proboscidea, Mammalia) dans le Miocène Inférieur d'Afrique orientale: Systématique et paléoenvironnement. Géobios 16: 53-77.

TOBIEN H. 1975. The Structure of the Mastodont Molar (Proboscidea, Mammalia) Part 2: The Zygodont and Zygobunodont Patterns, Mainz Geowiss Mitt 4: 195-233.

TOBIEN H, CHEN GF AND LI YQ. 1986. Mastodonts (Proboscidea, Mammalia) from the Late Neogene and
Early Pleistocene of the People's Republic of China. Part I: Historical account, the genera Gomphotherium, Choerolophodon, Synconolophus, Amebelodon, Platybelodon, Sinomastodon. Mainz Geowiss Mitt 15: 119-181.

TOBIEN H, CHEN GF AND LI YQ. 1988. Mastodonts (Proboscidea, Mammalia) from the Late Neogene and Early Pleistocene of the People's Republic of China. Part II: The genera Tetralophodon, Anancus, Stegotetrabelodon, Zygolophodon, Mammut, Stegolophodon. Mainz Geowiss Mitt 17: 95-220.

XIE GP. 2007. Identification on elephantoid teeth and fossil elephantoids in Gansu (in Chinese). In: EJ (Ed), The Collection of Disquisitions for West China's Museum Forum Contents. Lanzhou: Sanqin Press 152-181.

Wang S, ZhaO D, XIE G AND Sun B. 2014. An Asian origin for Sinomastodon (Proboscidea, Gomphotheriidae) inferred from a new Upper Miocene specimen from Gansu of China. Sci Ch Earth Sci 57(10): 2522-2531.

WANG SQ AND DENG T. 2011. The first Choerolophodon (Proboscidea, Gomphotheriidae) skull from China. Sci Chin Earth Sci 54: 1326-1337.

WANG SQ, LIU SP, XIE GP, LIU J, PENG TJ AND HOU SK. 2013. Gomphotherium wimani from Wushan County, China and its implications for the Miocene stratigraphy of the Tianshui Area. Vert Pal Asiat 51: 71-84.

WANG Y, CHANGZHU J, CHENGLONG D, GuANGBIAO W AND YALING Y. 2012. The first Sinomastodon (Gomphotheriidae, Proboscidea) skull from the Quaternary in China. Chin Sci Bull 57: 4726-4734. 